\title{
DEVELOPING ENGLISH TEACHING MATERIALS FOR ACCOUNTING STUDENTS: AN ESP APPROACH
}

\author{
Novrika Nartiningrum $^{1}$, Arif Nugroho ${ }^{2}$ \\ ${ }^{1}$ University of Muhammadiyah Malang, Indonesia \\ ${ }^{2}$ IAIN Surakarta, Indonesia \\ ${ }^{1}$ nnovrika@gmail.com, ${ }^{2}$ arifnugroho.iainsurakarta@gmail.com
}

\begin{abstract}
The contextualization of teaching materials with learners' needs is an absolute demand to achieve the success of a language learning. For this purpose, the present study aims to develop representative English materials for accounting students at IAIN Surakarta. Drawing on a research and development, this study was based on procedures adapted from Latief (2014), which followed several stages (1) need analysis; (2) prototype development; (3) experts validation; (4) field test/try-out; (5) product revision; and (6) dissemination and implementation. A questionnaire, focus group discussion, and semi-structured interview were employed to gather the data on students' needs and material feedbacks from 147 accounting students, 3 English teachers, and the head of accounting department at IAIN Surakarta. The results revealed that the students needed English materials that were closely related to accounting and business field. This study also resulted in a developed modul consisting of eight units, each unit presents reading, speaking, and writing skills that were contextualized with the students' needs. These results have filled the existing gap of providing representative materials to assist the students to develop their language skills in accounting and business environment.
\end{abstract}

Keywords: English for Accounting, Material Development, Need Analysis, Research and Development

\section{INTRODUCTION}

In university level, English is not only taught to students from English majors, but also taught to students from various majors, known as ESP or English for Specific Purposes. This teaching practice is encouraged by the importance of English in various lines of works (Bensafa, 2016). In order to equipped students with adequate English ability, students must be given enough resources to be able to have standard ability in communication using English (Nugroho, 2019). Students need reasonable amount of time and learning material in order to possess sufficient English skills for their future career (Susanto \& Latief, 2016). In line with this, IAIN Surakarta allocates 3 credits in semester 1 for ESP course. In this semester, ESP lecturers are expected to do their best in their teachings, one of many things that can be done by the lecturers is by providing effective and efficient teaching materials for their students.

Accounting students in IAIN Surakarta also need an effective and efficient English materials. This situation can be seen from a need analysis that has been done. The need analysis analyzed the Accounting students of IAIN Surakarta needs on English materials. The analysis mentioned that most of participants agreed that the current English materials are less related to Accounting. The participants also commented that teachers' understanding on terms and issues about Accounting was limited and the teachers were also not equipped with appropriate English materials. Furthermore, the result of questionnaire indicated that the students wanted to receive learning materials of language skills that were related to their major. The Focus Group 
Discussion held in the need analysis also mentioned that students needed learning materials related to Accounting because the students believed that the materials will be able to help them carry out their duties and assists the students to socialize in their future workplace.

Various majors, vast characteristics and needs of ESP students are few things that must be considered in arranging learning materials for ESP students (Aniqoh, 2018). Therefore, need analysis or preliminary study is conducted in order to gain information needed related to the development of the most suitable teaching materials for ESP students (Poedjiastutie and Rif'ah, 2019). Those information later can be used to identify learning objectives of the ESP course. As mentioned by Wardhani et al. (2017), conducting need analysis is considered as identifying the objectives.

Previous researches on material development tended to focus on one skill instead of integrating the four English skills. Puspa et al. (2018) developed a module for writing. The module was targeting in assisting Food Processing Technology Students in writing their apprenticeship report. Another study that developed materials for a specific skill was done by Rakhmawati et al. (2016). The center of that study was developing listening materials for seventh graders. While some of previous researches focused on one skill or one aspect of language, the present study tries to provide a teaching material that caters more than one skill. This study offers three skills as required by the students based on the need analysis. Moreover, the previous literature in teaching English for Specific Purposes has still silent on the development of representative materials for accounting students. Furthermore, the development of ESP module for accounting students is still minor in Indonesia. The insufficient exposure of English for Specific Purpose materials experienced by accounting students at IAIN Surakarta also inspired the present study to develop representative English teaching materials for accounting and finance fields.

Based on the description above, the present study aims to develop effective and appropriate teaching materials for accounting students that covers three language skills, namely: reading, speaking and writing. The procedures of development employed in this study are adapted from Latief (2014) which include (1) needs analysis; (2) prototype development; (3) experts validation; (4) field test/try-out; (5) product revision; and (6) dissemination and implementation. In order to ensure the objectives, this study is guided by the research question, "how are English teaching materials for accounting students developed?"

\section{METHOD}

The present study sheds some light on the development of English teaching materials for accounting students. To this end, a research and development model proposed by Latief (2014) were followed. The procedures of development adapted in this study consisted of several satages: (1) needs analysis; (2) prototype development; (3) experts validation; (4) field test/tryout; (5) product revision; and (6) dissemination and implementation.

The researchers collected the data from 147 accounting students, 3 English teachers, and the head of accounting department at IAIN Surakarta. They were involved in this study voluntarily upon invitation. The data were obtained by means of focus group discussion, web-based questionnaire, and semi-structured interview. They provided valuable data and information to be used as a basis of developing English materials for accounting students.

First of foremost, a need analysis was employed to examine the accounting students' needs of English teaching materials. It was administered by conducting a focus group discussion (FGD) with 16 students of accounting department to obtain initial points about their needs of language 
skills. They were conveniently selected to participate in FGD session for 120 minutes. The results of FGD were then formulated in a web-based questionnaire and was distributed to 147 (70\%) first-year accounting students at IAIN Surakarta through social media WhatsApp (the most frequently used instant massager in Indonesia). The questionnaire consisted of eight items examining the students' needs of language skills. To enrich the data, follow up semi-structured interviews were also conducted with 3 English teachers and the head of accounting students. The results of need analysis were further used as a basis of prototype development of the English for accounting module.

Second, a prototype of English for accounting module was developed. The researchers started with analyzing the results of the need analysis and drew conclusions about learning materials that were urgently needed by the students. In order to develop the acceptable teaching materials, the present study used the results of need analysis as a guidance to arrange the units in the teaching materials. Afterwards, to ensure the quality of the prototype module, the researchers searched for suitable passages, authentic materials and drafts of the activities which were closely related to accounting and were able to fulfil students' needs. Then, the researcher developed materials that had been acquired and arranged them in the form of a complete module for accounting students.

Third, to ensure the quality, validity, and reability of the module, experts validation was administered. Three experts majoring in accounting and finance, economics and business, and English grammar were involved in this stage. After appointing the experts, the researchers gave the prototype module along with the feasibility test questionnaires. It took about a month for the experts to evaluate the English for accounting module. Later, the module was given back to the researchers attached with the assessments in the form of questionnaires and notes. The revisions form the experts were utilized as evaluation and improvement materials before advancing to the try-out phase.

Fourth, field test/try-out was performed to examine the practicality of the module. It involved 117 accounting students and 3 English teachers at IAIN Surakarta. The three English teachers were assigned to teach 117 students that were divided into three classes. The try-out process employed four meetings. The samples taken were four units out of eight units available in the module. Therefore, one unit was applied for one meeting. After implementing the module for the teaching and learning activities, the students were given questionnaire in order to assess and evaluate the quality and the eligibility of the module (see table 3). The results of the try-out were used as input to do the module revision before the dissemination was conducted.

\section{RESULTS AND DISCUSSION}

\section{Results}

In general, the results of need analysis indicate that accounting students of IAIN Surakarta require representative English materials that have connections with accounting and are expected to be able to assist them in their future career. The results of need analysis further reveal that accounting students need English for contextualized workplace environment in accounting field. The students' needs were portrayed by administering FGD and web-based questionnaire to accounting students. In addition, semi-structured interviews were conducted with the English teachers and the head of accounting department. 
Table 1. Result of Need Analysis

\begin{tabular}{|c|c|c|c|c|c|c|c|}
\hline \multirow{2}{*}{ No } & \multirow{2}{*}{ Items } & \multicolumn{4}{|c|}{ Responses (n=147) } & \multirow{2}{*}{ Total } & \multirow{2}{*}{$\begin{array}{c}\text { Index } \\
(\%)\end{array}$} \\
\hline & & SD & $\mathrm{D}$ & $\mathrm{A}$ & $\mathrm{SA}$ & & \\
\hline 1 & $\begin{array}{l}\text { I need English materials to develop my language } \\
\text { skills (speaking, writing, reading, and listening). }\end{array}$ & 0 & 4 & 201 & 312 & 517 & 87,93 \\
\hline 2 & $\begin{array}{l}\text { I need English materials to support my } \\
\text { performance in workplace environment. }\end{array}$ & 0 & 0 & 273 & 224 & 497 & 84,52 \\
\hline 3 & $\begin{array}{l}\text { I need English materials to develop my } \\
\text { professional functions (meeting, presentation, } \\
\text { writing financial report, etc). }\end{array}$ & 0 & 6 & 69 & 484 & 559 & 95,07 \\
\hline 4 & $\begin{array}{l}\text { I need English materials for casual } \\
\text { environment/daily conversation with colleagues. }\end{array}$ & 0 & 2 & 138 & 400 & 540 & 91,84 \\
\hline 5 & $\begin{array}{l}\text { I need English materials for vocabulary acquisition } \\
\text { in Accounting and business. }\end{array}$ & 0 & 4 & 195 & 320 & 519 & 88,27 \\
\hline 6 & $\begin{array}{l}\text { I need more representative English materials to } \\
\text { meet my needs of language skill in Accounting } \\
\text { field. }\end{array}$ & 0 & 2 & 39 & 532 & 573 & 97,45 \\
\hline 7 & $\begin{array}{l}\text { The duration of English course for accounting } \\
\text { students needs to be extended. }\end{array}$ & 0 & 2 & 33 & 540 & 575 & 97,79 \\
\hline 8 & $\begin{array}{l}\text { My English course offers me general English } \\
\text { instead of English for Accounting. }\end{array}$ & 0 & 0 & 81 & 480 & 561 & 95,41 \\
\hline
\end{tabular}

Notes: $0-25 \% \quad$ : strongly disagree

$26-50 \% \quad$ : disagree $\quad 76-100 \% \quad$ : strongly agree

As depicted in table 1, based on students' response on the item "I need English materials to (for)...", the highest percentage is $95.07 \%$. The students answered that they need English materials mostly to develop their professional functions (meeting, presentation, writing financial report, etc.). This purpose is followed by casual environment/daily conversation with colleagues since $91.84 \%$ of the students agreed that English materials are needed for that reason. Vocabulary acquisition in accounting and business reason comes third as $88.27 \%$ of the students agreed that English materials are needed for that purpose. Developing language skills (speaking, writing, reading and listening) becomes the fourth reason for the students to ask for English materials since $87.93 \%$ of the students agreed on that. Supporting performance in workplace environment comes last in order because $84.52 \%$ of the students agreed on it.

Table 1 also shows that $97.45 \%$ of students need more representative English materials to meet their needs of language skill in accounting field, $97.79 \%$ of students agreed that the duration of English course for accounting needs to be extended and $95.41 \%$ of students mentioned that their English course offered them general English instead of English for accounting. One of the interesting points is that the duration of English course needs to be extended. In this case, 3 credits in one semester have been decided by the university. One of the solutions that can be done in order to optimize the time allocation given is by developing representative English materials which can improve students' ability in using English for their specific purposes.

Another issue that emerges from need analysis is that most ESP teachers taught general English instead of English for Specific Purposes. This situation can be caused by lack of ESP materials 
in the university. Therefore, that phenomenon urges the development of English materials for ESP students.

\section{Results of prototype development}

The result of English teaching material development for accounting students covers 8 units with three sections for three skills namely: reading, speaking and writing. Those three sections are explained as follows.

The reading sections are always started with pre-reading activities that are simple and fun activities. The activities are meant to evoke students' interest in the main reading activities that will be done later on. Moreover, engaging students' attention before main reading activities is also important because the main reading activities will ask for sufficient focus and attention. This activity not only catches students' attention but also equips students with the meaning of the key word to understand the text that follows. The use of colorful illustration is also effective to grab students' interest. Furthermore, the pre-reading activity also aims to relate students' background knowledge to the reading passage. Therefore, clearer understanding of the key words is assured and will be able to assist students in understanding the text better. For example, in unit 6 , the students are asked to match the definitions with the correct terms. The terms are provided with colorful illustrations that can help students to understand the terms mentioned in the task.

The main reading text is followed by various activities such as finding specific information, deciding whether the statements are true or false, classifying some characteristics/statements into their categories, filling the gaps and checklist, or matching the words with their meanings. The diverse activities attempt to hinder students' boredom of WH questions. The increasing difficulty level can also be seen from the activities in the next units. Activities that will enrich students' vocabulary related to accounting are also found in each unit.

The speaking section starts off with the basic but important activities, which are introducing oneself and others. This introduction activities are in line with the need of accounting students. It can be seen from the guideline given in each unit. After giving a simple guidelines, students are asked to practice the introduction. The speaking activities do not only include individual works, but also peer works. Peer works can be used to ease students' anxiety when speaking. The use of colorful illustration is also usually needed by students, as mentioned by Hakim (2018) that $100 \%$ of the students mentioned that they really need illustration like pictures in their speaking instructional materials.

Furthermore, the writing section begins with brief explanation about the kind of text that will be written. Other than giving a short description, the next part provides the objective of the writing activity. Then, few tips for writing the specific text are presented. Next, a suitable example is also available. After reading the example, students are expected to identify the organization of the text in the next activity. The existence of the example and the analysis of text organization are important because it is essential for students to read a sample first, analyze the sample to see the organization of the text in order to model the sample later for their own piece of written production as mentioned by Tomak and Ataş (2019) in their study. For instance, in unit 8, students are given a complete example of an application letter. The students are expected to be able to write their own application letters by modelling the available example.

\section{Result of Experts Validation}

Before implementing the try out, the module needed to be validated. The validators included three experts who would give scores to the following aspects; clarity, content, language, 
instructions, activities model and layout. The maximum score of the validation is 15 . The meanings of the classification are; $0-20 \%$ means not acceptable, $21-40 \%$ means below expectation, $41-60 \%$ means sufficient, $61-80 \%$ means meet the expectation and $81-100 \%$ means exceed the expectation.

Table 2. Results of Experts Validation

\begin{tabular}{|c|c|c|c|c|c|c|c|}
\hline \multirow{2}{*}{ Criteria } & \multicolumn{3}{|c|}{ Responses $(n=3)$} & \multirow{2}{*}{$\begin{array}{l}\text { Total } \\
\text { Score }\end{array}$} & \multirow{2}{*}{$\begin{array}{l}\text { Max } \\
\text { Score }\end{array}$} & \multirow{2}{*}{$\begin{array}{c}\text { Index } \\
(\%)\end{array}$} & \multirow{2}{*}{ Classification } \\
\hline & Expert 1 & Expert 2 & Expert 3 & & & & \\
\hline Clarity & 5 & 4 & 4 & 13 & 15 & 86,6 & $\begin{array}{l}\text { Exceed } \\
\text { expectation }\end{array}$ \\
\hline Content & 5 & 4 & 3 & 12 & 15 & 80,0 & Meet expectation \\
\hline Language & 4 & 5 & 3 & 12 & 15 & 80,0 & Meet expectation \\
\hline Instructions & 3 & 3 & 4 & 10 & 15 & 66,6 & sufficient \\
\hline $\begin{array}{l}\text { Activities } \\
\text { model }\end{array}$ & 3 & 5 & 4 & 12 & 15 & 80,0 & Meet expectation \\
\hline Layout & 4 & 3 & 5 & 12 & 15 & 80,0 & Meet expectation \\
\hline
\end{tabular}

Table 2 depicts that in terms of clarity, the three experts agreed that the module has exceeded the expectation (86.6\%). In terms of content, language, activities model and layout, the module has met the expectation (80.0\%). The instructions in the module are also considered sufficient (66.6\%) according to the three experts. Along with the results of validation questionnaire, the experts provided some insights and improvements to enhance the quality of the module.

\section{Results of Try-out}

After administering the try-out to 117 students, the clarity, content, language, instructions, activities model and layout are given score as can be seen in Table 3. The data were obtained by means of paper-based questionnaire. The maximum score of the try out result is 585 . The meanings of the classification are; 0-20\% means not acceptable, 21-40\% means below expectation, $41-60 \%$ means sufficient, $61-80 \%$ means meet the expectation and $81-100 \%$ means exceed the expectation.

Table 3. Results of Try-out

\begin{tabular}{lccccl}
\hline \multicolumn{1}{c}{ Criteria } & N & $\begin{array}{c}\text { Total } \\
\text { Score }\end{array}$ & $\begin{array}{c}\text { Maximum } \\
\text { Score }\end{array}$ & $\begin{array}{c}\text { Index } \\
\mathbf{( \% )}\end{array}$ & Classification \\
\hline Clarity & 117 & 467 & 585 & 79,82 & Meet expectation \\
Content & 117 & 563 & 585 & 96,23 & Exceed expectation \\
Language & 117 & 526 & 585 & 89,91 & Exceed expectation \\
Instructions & 117 & 498 & 585 & 85,12 & Exceed expectation \\
Activities model & 117 & 486 & 585 & 83,07 & Exceed expectation \\
Layout & 117 & 521 & 585 & 89,05 & Exceed expectation \\
\hline
\end{tabular}

The result of the try out shows that in terms of content, language, instructions, activities model and layout, the module has exceeded the expectation. The content comes with the highest score 
(563), followed by language (526), layout (521), instructions (498) and activities model (486). The clarity of the module comes last in score (467). However, with the index of $79.82 \%$, the module's clarity still meets the expectation. In addition to students' responses of the questionnaire, they were also assigned to write suggestions and improvement for the betterment of English for accounting module. Their suggestions were further used as a basis of conducting the final revision before dissemination stage.

\section{Discussion}

The findings show that the teaching material for accounting students at IAIN Surakarta that has been developed is quite representative and reflect the students' field of study and it is possibly able to support students' academic success and career development. In terms of developing teaching materials, the results of this study are similar with the findings of Puspa et al. (2018) and Rakhmawati et al. (2016). However, the present study develops materials for more than one English skills. In Puspa's et al. (2018) research, writing skill becomes the main aspect of the teaching material. They aimed to assist Food Processing Technology Students in writing their apprenticeship report by following the module that was developed. Similary, Rakhmawati et al. (2016) developed materials for a specific skill. They were developing listening materials for seventh graders.

The present study showed some differences. First, the teaching material developed in this study presents more than one skill. This teaching material consists of three sections; reading section, speaking section and writing section. Second, the targets of the teaching material developed in this research are college students from Accounting Department. Moreover, the difficulty level of each unit was arranged from the easiest to more challenging ones. The reading section begins with pre-reading activity to facilitate students in understanding the main text well. The reading exercises are available in various forms that will interest the students. The simplest materials are given in the early units so that students will not feel discouraged to learn the materials. Then, more challenging materials are given in the next units so that students' skills are improved gradually.

The developed materials show that the speaking section starts with short explanation about the expressions that can be used by students in speaking practice. The teaching material also provides guidance for the students to follow and examples for them to model. The exercises look fun and engaging with colorful pictures and illustrations that will ease students' challenges in imagining the situations they are speaking in. Individual and peer works are catered in the speaking section. Individual activities will be effective for students who already have high confidence in speaking. These confident students are usually eager and highly motivated to show their abilities and ideas. In order to facilitate these students, individual works are presented in the speaking sections. On the other hand, more introverted students or students who lack of speaking skills tend to prefer peer works. Therefore, peer works are also available in the teaching materials to assist less confidence students who feel more comfortable in speaking in pairs or groups.

Lastly yet importantly, the writing section begins with brief description of the writing objectives. A succinct description about the kind of text and some tips in writing the text are also available. Moreover, a good example of the text can also be found in the teaching material. Furthermore, students are not asked to create the text right away. Students can identify/analyze the organizations of the text first by doing the prepared exercise. With this, students are expected to be able to build a good text by following the guidelines, modelling the example and 
understanding the organization of the text. Reading the guidelines and the example will help students to picture the kind of text that they will be writing. Then, identifying the text organization will assist students to be able to write their own text later. These increasing levels of difficulties will make students feel interested, encouraged and challenged to produce good pieces of written works.

Considering the explanation above, this paper offers some practical contributions to the realm of English language teaching, especially in teaching ESP. The first contribution is that the present study provides a good ESP teaching materials for accounting students. The teaching materials developed in this study consists of three English language skills, namely; reading, speaking and writing. The emergence of those three skills are based on the need analysis that was carried out in this study. Besides, a research conducted by Alsamadani (2017) which investigated the English language needs of 200 engineering students majoring in civil engineering and industrial engineering found out that reading, speaking and writing were needed more than others. In line with Alsamadani (2017), Madkur (2018) learned that the most important language skills according to teaching assistants in the study were writing, speaking and reading.

The second contribution presented by the present study is that the developed teaching materials can function as an example for other ESP lecturers who want to develop similar teaching materials for accounting students. There are not many ESP teaching materials for accounting students that have been developed. Many of previous researches have offered need analysis on various majors, such as a research done by $\mathrm{Li}$ (2014) which focused on the implementation of need analysis in Business English curriculum design. The research mentioned that need analysis is an effective way for Business English curriculum design.

\section{CONCLUSION}

Considering the findings and the discussion, it can be concluded that the teaching material for accounting students developed in this research is a fairly good ESP teaching material. The three sections are arranged well following the difficulty level in each unit that is more challenging for the students. The activities are well thought out, allowing the students to be prepared for the materials and to enjoy doing the exercises. However, it must be understood that there is one skill that has no section in this teaching material although the listening practices are unconsciously integrated in the available sections in the teaching material. Still, the authors suggest the future researchers to also provide a section for listening so that the four English skills are be able to be learned simultaneously. Finally, ESP teaching material is better to have more than one skill and expose more on specific purposes, not general English because the ESP course is expected to equipped students with sufficient English skills for their future professional career.

\section{ACKNOWLEDGMENTS}

The researchers have to acknowledge the respondents who are voluntarily involved in this study, i.e. first-year accounting students, English teachers, and the head of accounting department of IAIN Surakarta.

\section{REFERENCES}

Alsamadani, H. A. (2017). Needs Analysis in ESP Context: Saudi Engineering Students as a Case Study, Advances in Language and Literary Studies, 8(6), 58-68.

Aniqoh, A. N. I. K. (2018). Need Analysis of Esp Materials for The Medical Laboratory 
Technology Students in The Health Polytechnics Semarang (Doctoral dissertation, Thesis: Muhammadiyah University Of Surakarta).

Bensafa, A. (2016). ESP Materials Adaptation: Bridging the Gap between Theory and Practice. $7(7), 254-260$.

Latief, M. A. (2014). Research Methods on Language Learning: An Introduction. Malang: Universitas Negeri Malang Press.

Li, J. (2014). Needs Analysis: An Effective Way in Business English Curriculum Design, Theory and Practice in Language Studies, 4(9), 1869-1874.

Madkur, A. (2018). English for specific purposes: A need analysis on English course in Islamic banking department. Lingua Cultura, 12(3), 221-226.

Nugroho, A. (2019). Request Realizations of Indonesian Esp Lecturers. Celtic: A Journal of Culture English Language Teaching Literature \& Linguistics, 6(1), 1. https://doi.org/10.22219/celticumm.vol6.no1.1-13

Poedjiastutie, D., \& Rif'ah, L. (2019). English Communication Needs of Engineering Students. International Journal of Language and Linguistics, 7(2), 69.

Puspa, A., Latief, M. A., \& Iragiliati, E. (2018). English for Academic Purposes : E-Module of Writing a Report for Food Processing Technology Students. Jurnal Pendidikan, 3(3), 371376.

Rakhmawati, I., Iragiliati, E., \& Rachmajanti, S. (2016). Developing Supplementary Multimedia- Based Listening Materials for the Seventh Graders, Jurnal Pendidikan, 3(3), 940-947.

SSusanto, J., \& Latief, M. A. (2016). Developing English teaching material for midwifery students. The Journal of Teaching English for Specific and Academic Purpose, 4(3), 527 537.

Tomak, B., \& Ataş, U. (2019). Designing an Esp Writing Course for Pre-Intermediate Efl Engineering Students. Journal of Teaching English for Specific and Academic Purposes, 267-282.

Wardhani, L. S., Latief, M. A., \& Basthomi, Y. (2017). Developing English Course Book For Second Grade Kindergarteners. Jurnal Pendidikan: Teori, Penelitian, dan Pengembangan, 2(6), 840-847. 